\title{
Expression of TRPC1 and SBEM protein in breast cancer tissue and its relationship with clinicopathological features and prognosis of patients
}

\author{
YONGQING ZHANG, XIAOQIN LUN and WEILING GUO \\ Department of General Surgery, Weifang People's Hospital, Weifang, Shandong 261041, P.R. China
}

Received October 4, 2019; Accepted July 22, 2020

DOI: $10.3892 / \mathrm{ol} .2020 .12255$

\begin{abstract}
This study investigated the relationship of the expression of transient receptor potential channel 1 (TRPC1), small breast epithelial mucin (SBEM) in breast cancer tissues with clinical pathological features and prognosis of patients. Altogether 50 patients with breast cancer who were treated in Weifang People's hospital from April 2017 to November 2018 were selected, and the mRNA and protein differences of TRPC1 and SBEM in breast cancer patients and normal breast cancer tissues were detected by qRT-PCR and Western blot. Spearman test was used for correlation analysis. Logistic univariate and multivariate analysis were performed on the risk factors related to breast cancer metastasis in breast cancer patients. The expression of TRPC1 and SBEM in breast cancer tissues was significantly higher than that in normal breast tissues $(\mathrm{P}<0.001)$. The mRNA expression of TRPC1, SBEM and protein was not related to age, tumor size and tissue grade of breast cancer patients, but related to TNM stage, clinical stage and lymph node metastasis $(\mathrm{P}<0.001)$. The relative expression of TRPC1 was positively correlated with clinical stage of breast cancer $(r=0.992, \mathrm{P}<0.001)$. The relative expression of SBEM was positively correlated with the clinical stage of breast cancer $(\mathrm{r}=0.853, \mathrm{P}<0.001)$. The relative expression of TRPC1 was positively correlated with TNM staging of breast cancer $(\mathrm{r}=0.860, \mathrm{P}<0.001)$. The relative expression of SBEM was positively correlated with TNM staging of breast cancer $(\mathrm{r}=0.880, \mathrm{P}<0.001)$. Multivariate conditional Logistic regression analysis showed that TNM staging, TRPC1, SBEM were independent risk factors for malignant breast cancer metastasis. On the contrary, expression of TRPC1 and SBEM in breast cancer tissues was up-regulated. TRPC1 and SBEM may be involved
\end{abstract}

Correspondence to: Dr Weiling Guo, Department of General Surgery, Weifang People's Hospital, 151 Guangwen Street, Weifang, Shandong 261041, P.R. China

E-mail: wy725j@163.com

Key words: TRPC1, SBEM, breast cancer, clinicopathological features, prognosis, biomarkers in the process of breast cancer occurrence, development and metastasis, and can be used as potential tissue biomarkers in diagnosis of breast cancer metastasis and disease assessment.

\section{Introduction}

Breast cancer mainly occurs in glandular epithelial tissue of breast and is one of the most common malignant tumors in women (1). Breast cancer has a great impact on physical and mental health of women, and even endangers their lives in serious cases. According to statistics, the incidence rate of breast cancer in the world is increasing year by year $(2,3)$. At present, the clinical treatment for breast cancer is mainly surgical operation, radiotherapy, chemotherapy, endocrine therapy and auxiliary treatment of traditional Chinese medicine. Surgical resection, the main treatment for patients with advanced breast cancer, is divided into breast-conserving therapy and total mastectomy. Total mastectomy is performed for breast cancer patients who are not suitable for breast conserving surgery and has a great impact on the physical and psychological well-being of the patients $(4,5)$. Since most surgical patients are already in advanced stage of breast cancer at the time of treatment, breast cancer is likely to metastasize even if the cancerous tissue is removed (6). Statistics show that the recurrence rate of breast cancer metastatic patients is high and the 5-year survival rate is low (7). Clinically, the etiology of breast cancer is not completely clear, so early diagnosis of breast cancer patients can be carried out to improve the survival rate (8).

With the continuous expansion of research on molecular biology related to breast cancer in recent years, molecular targeted therapy is one of the most active research fields at present (9). Molecular targeting plays an important role in the diagnosis, staging and comprehensive treatment of breast cancer. Transient receptor potential channel 1 (TRPC1) and small breast epithelial mucin (SBEM) were shown to be up-regulated in breast cancer tissues and cells, and were related to breast cancer metastasis. It has been reported that SBEM protein in breast cancer patients can be detected to monitor the condition of breast cancer, and down-regulation of SBEM gene expression can inhibit the proliferation of breast cancer cells (10). A recent research report suggests that a protein called Transient receptor potential channel 1 (TRPC1) is closely related to the occurrence and development of tumors. TRPCI belongs to non-selective 
cation channel families. TRPCI produces channels for calcium and sodium ions to enter. These channels are closely related to cell adhesion and drug resistance of cancer cells. It is particularly important to determine the tools of TRPCI physiology and the pathophysiological functions of TRPC channels (11). Among them, TRPCI protein has been proved to be abnormally up-regulated in renal carcinoma, liver cancer, breast non-invasive ductal carcinoma and other solid tumors (12). However, there is lack of research on the expression and predictive value of TRPC1 and SBEM in breast cancer. Therefore, our study aimed to provide a new theoretical basis for the diagnosis and treatment of breast cancer in molecular biology and to find suitable molecular markers specific to breast cancer. Predictive value was explored of TRPCI and SBEM protein in breast cancer metastasis, and whether they play an important role in the diagnosis, staging and comprehensive treatment of breast cancer.

\section{Patients and methods}

Data collection and patients. From April 2017 to November 2018, 50 female patients with breast cancer diagnosed by surgery or biopsy were selected. The patients were aged $29-59$ years, with the average age of $50.43 \pm 1.02$ years. Inclusion criteria: Breast cancer patients admitted to the hospital; the tissue samples were all examined by general surgery and pathology department and the patients were confirmed as breast cancer (13); no radiotherapy, chemotherapy or other treatment was performed. Exclusion criteria: Patients with other preoperative complications; patients with conscious, cognitive and other mental disorders; pregnant women and patients with other contraindications. The study was approved by the Ethics Committee of Weifang People's Hospital (Weifang, China). Patients who participated in this research had complete clinical data and signed informed consents were obtained from the patients and/or guardians.

\section{Main reagents, instruments and detection methods}

Main reagents and instruments. Trizol Reagent (Applied; Invitrogen), qRT-PCR kit and minScript Reverse Transcription kit (Takara), HBS-1096A Enzyme Labeling Analyzer (Nanjing Detie Experimental Equipment Co., Ltd.), and Real-time Quantitative PCR instrument (BioRad) were applied. Primer sequence of TRPC1, SBEM, and internal reference Glyceraldehyde-3-phosphate dehydrogenase (GAPDH) and miRNA negative control were designed by Shanghai Gene Pharma. The sample was not treated before administration (Table I).

Detection of mRNAs encoding TRPCI and SBEM. qRT-PCR was used to detect the expression of TRPC1 and SBEM in tissues. Total RNA of tissues was extracted according to Trizol reagent operation instructions and dissolved in $20 \mu \mathrm{l}$ of DEPC water. The total RNA was then reverse transcribed using a reverse transcription kit. The reaction system was as follows: $1 \mu \mathrm{l}$ of M-MLV, $1 \mu \mathrm{l}$ of Olig (d T), $0.5 \mu \mathrm{l}$ of RNA enzyme inhibitor, $1 \mu \mathrm{l}$ of d NTPs, RNase free water was supplemented to $15 \mu \mathrm{l}$. The sample was incubated at $38^{\circ} \mathrm{C}$ for $60 \mathrm{~min}$. cDNA (1 $\mu \mathrm{l}$ ) was taken at $85^{\circ} \mathrm{C}$ for $5 \mathrm{sec}$ and the synthesized cDNA was used as a template for qRT-PCR amplification. The PCR reaction system was as follows: $2.5 \mu \mathrm{l}$ of 10X PCR buffer, $1 \mu \mathrm{l}$ of dNTPs, $1 \mu \mathrm{l}$ of upstream and downstream primers, $0.25 \mu \mathrm{l}$ of Taq DNA polymerase, dd $\mathrm{H}_{2} \mathrm{O}$ was supplemented to $25 \mu \mathrm{l}$. Reaction conditions were as follows: Pre-denaturation at $95^{\circ} \mathrm{C}$ for $15 \mathrm{~min}$, denaturation at $95^{\circ} \mathrm{C}$ for $15 \mathrm{sec}$, annealing at $60^{\circ} \mathrm{C}$ for $30 \mathrm{sec}$, for a total of 35 cycles. Finally, the sample was extended for $15 \mathrm{~min}$ at $72^{\circ} \mathrm{C}$. Each sample was provided with three multiple wells for three repeated experiments, with GAPDH as the internal reference for TRPC1 and SBEM. After the reaction was completed, the amplification curve and melting curve of Real-Time PCR were confirmed, and the relative amount of the target gene was calculated according to the result parameters. The relative quantification of target gene was calculated by $2^{-\Delta \Delta \mathrm{CT}}$ (Table I).

Detection of the expression of TRPC1, SBEM and GAPDH protein by western blot. Breast cancer tissues of 50 patients with breast cancer and normal breast tissues adjacent to the cancer were put into a precooled mortar, and the tissue was ground into powder in liquid nitrogen. After the protein lysate was added, the total protein in the tissue was separated and placed into a homogenizer (Shanghai Active Motif Biotechnology Co., Ltd., item no. 40401/40415), $300 \mu 1$ of lysate was added and the tissue mass gradually disappeared through grinding until the lysate was free of impurities and precipitates, then the sample was cracked on ice for $30 \mathrm{~min}$ and centrifuged at $20,000 \mathrm{x}$ g for $20 \mathrm{~min}$ at $4^{\circ} \mathrm{C}$, and finally the supernatant was taken as the total cell protein. BCA protein quantification was carried out by $6-12 \%$ of sodium dodecyl sulfate polyacrylamide gel electrophoresis and transferred to polyvinylidene fluoride membrane. After selecting the corresponding band according to the target protein, the sample was sealed with defatted milk powder with concentration of $5 \%$ for $2 \mathrm{~h}$. After rinsing the membrane, $2 \mathrm{ml}$ of western primary antibody dilution buffer (Beyotime Biotechnology) with dilution ratio of 1:1,000 was added and placed at $4^{\circ} \mathrm{C}$ over night. After the first antibody was re-warmed for $30 \mathrm{~min}$ before the experiment on the second day, western second antibody (Beyotime Biotechnology) was incubated for $1 \mathrm{~h}$ with the same procedure, and developer was added in the dark for exposure. PVDF film was imaged by Tocan 240 automatic gel imaging system (Shanghai Tocan Bio-technology Co., Ltd.) and the results were analyzed by Image $\mathrm{Lab}^{\mathrm{TM}}$ software.

Statistical analysis. SPSS v17.0 software system was used for statistical analysis. Counting data was expressed by the number of cases/percentage $n(\%)$, and $\chi^{2}$ test was used for comparison between the two groups. The measurement data were expressed by mean number $(\mathrm{X} \pm \mathrm{sd})$, and the comparison between groups was conducted by t-test or F-test. Spearman test was used for correlation analysis. Logistic univariate and multivariate analysis were performed on the risk factors related to breast cancer metastasis in breast cancer patients. $\mathrm{P}<0.05$ was considered to indicate a statistically significant difference.

\section{Results}

General clinical data of patients. The age, tumor size, TNM stage, clinical stage and lymph node metastasis of breast cancer tissue and normal breast tissue were compared (P>0.05; Table II). 
Table I. Primer sequences of TRPC1, SBEM and internal reference GAPDH.

\begin{tabular}{lll}
\hline Group & \multicolumn{1}{c}{ Upstream primer } & \multicolumn{1}{c}{ Downstream primer } \\
\hline TRPC1 & 5'-GCCAGTTTTGTCACTTTGTTATTT-3' & 5'-CCCATTGTGTTTTTCTTATCCTCA-3' \\
SBEM & 5'-TAGAGCTAGCGAATTATGAAGTTCTTAGCAGTCC-3' & 5'-AGATCCTTCGCGGCCTCAGGGAC \\
& & ACACTCTACCA-3' \\
GAPDH & 5'-CGCTGAGTACGTCGTGGAGTC-3' & 5'-GCTGATGATCTTGAGGCTGT \\
& & TGTC-3'
\end{tabular}

The upstream/downstream primer sequences of TRPC1, SBEM and GAPDH.

Table II. General clinical data of patients.

\begin{tabular}{|c|c|}
\hline Group & $\mathrm{n}(\%)$ \\
\hline \multicolumn{2}{|l|}{ Age, years } \\
\hline$\leq 50$ & $25(50.00)$ \\
\hline$>50$ & $25(50.00)$ \\
\hline BMI $\left(\mathrm{kg} / \mathrm{m}^{2}\right)$ & $19.20 \pm 1.04$ \\
\hline \multicolumn{2}{|l|}{ Residence } \\
\hline Urban & $38(76.00)$ \\
\hline Rural & $12(24.00)$ \\
\hline \multicolumn{2}{|l|}{ Educational level } \\
\hline Junior high school & $6(12.00)$ \\
\hline High school & $14(28.00)$ \\
\hline Bachelor degree or above & $30(60.00)$ \\
\hline \multicolumn{2}{|l|}{ Histological classification } \\
\hline Level 1+level 2 & $26(52.00)$ \\
\hline Level 3 & $24(48.00)$ \\
\hline \multicolumn{2}{|l|}{ Tumor size, $\mathrm{cm}$} \\
\hline$\leq 2$ & $23(46.00)$ \\
\hline$>2$ & $27(54.00)$ \\
\hline \multicolumn{2}{|l|}{ Clinical staging } \\
\hline Phase I & $10(20.00)$ \\
\hline Phase II & $17(34.00)$ \\
\hline Phase III & $14(28.00)$ \\
\hline Phase IV & $9(18.00)$ \\
\hline \multicolumn{2}{|l|}{ TNM staging } \\
\hline $\mathrm{T} 1$ & $10(20.00)$ \\
\hline $\mathrm{T} 2$ & $18(36.00)$ \\
\hline $\mathrm{T} 3$ & $13(26.00)$ \\
\hline $\mathrm{T} 4$ & $9(18.00)$ \\
\hline \multicolumn{2}{|l|}{ Lymph node metastasis } \\
\hline No & $40(80.00)$ \\
\hline Yes & $10(20.00)$ \\
\hline
\end{tabular}

General clinical data of patients were included in Table.

Expression of TRPC1, SBEM protein and $m R N A$ in breast cancer tissue and normal breast tissue. qRT-PCR results showed that the expression of TRPC1 in breast cancer tissue and normal breast tissue were $(1.50 \pm 0.03),(0.20 \pm 0.01)$ respectively.
Table III. Relationship between mRNA expression of TRPC1 and clinicopathological features of breast cancer.

\begin{tabular}{|c|c|c|c|c|}
\hline Group & $\mathrm{n}$ & TRPC1 & $\mathrm{t} / \mathrm{F}$ & P-value \\
\hline Age, years & & & 2.000 & 0.051 \\
\hline$\leq 50$ & 25 & $1.49 \pm 0.04$ & & \\
\hline$>50$ & 25 & $1.51 \pm 0.03$ & & \\
\hline $\begin{array}{l}\text { Histological } \\
\text { classification }\end{array}$ & & & 1.397 & 0.169 \\
\hline Level 1+level 2 & 26 & $1.50 \pm 0.02$ & & \\
\hline Level 3 & 24 & $1.51 \pm 0.03$ & & \\
\hline Tumor size, $\mathrm{cm}$ & & & 2.017 & 0.05 \\
\hline$\leq 2$ & 23 & $1.49 \pm 0.04$ & & \\
\hline$>2$ & 27 & $1.51 \pm 0.03$ & & \\
\hline Clinical staging & & & $5,704.000$ & $<0.001$ \\
\hline Phase I & 10 & $0.80 \pm 0.03$ & & \\
\hline Phase II & 17 & $1.07 \pm 0.03$ & & \\
\hline Phase III & 14 & $1.77 \pm 0.03$ & & \\
\hline Phase IV & 9 & $2.35 \pm 0.03$ & & \\
\hline TNM staging & & & $6,337.000$ & $<0.001$ \\
\hline $\mathrm{T} 1$ & 10 & $0.87 \pm 0.02$ & & \\
\hline $\mathrm{T} 2$ & 18 & $1.00 \pm 0.03$ & & \\
\hline T3 & 13 & $1.82 \pm 0.03$ & & \\
\hline $\mathrm{T} 4$ & 9 & $2.30 \pm 0.03$ & & \\
\hline $\begin{array}{l}\text { Lymph node } \\
\text { metastasis }\end{array}$ & & & 140.000 & $<0.001$ \\
\hline No & 40 & $1.00 \pm 0.02$ & & \\
\hline Yes & 10 & $2.10 \pm 0.03$ & & \\
\hline
\end{tabular}

TRPC1 mRNA expression level and age, histological grade, tumor size, clinical stage, TNM stage, lymph node metastasis.

Expression of SBEM in breast cancer tissue and normal breast tissue were $(0.50 \pm 0.02),(0.10 \pm 0.01)$ respectively. Western blot results showed that the expression of TRPC1 protein in breast cancer tissues and normal breast tissues were $(1.60 \pm 0.03)$, $(0.20 \pm 0.02)$ respectively. Expression of SBEM protein in breast cancer tissue and normal breast tissue was $(0.60 \pm 0.01)$, $(0.09 \pm 0.01)$ respectively. Compared with the two groups, the expression of TRPC1 protein and mRNA in breast cancer tissues was significantly higher than that in normal breast 
A

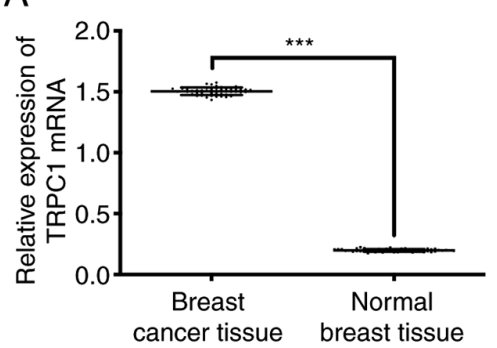

B

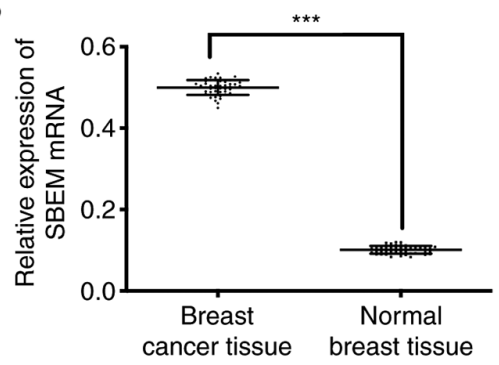

C

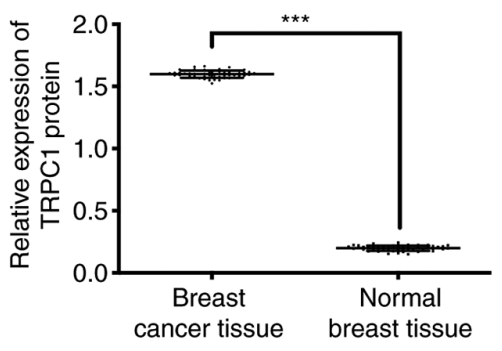

D

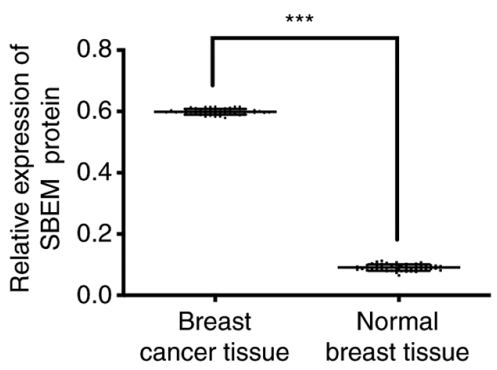

$\mathrm{E}$

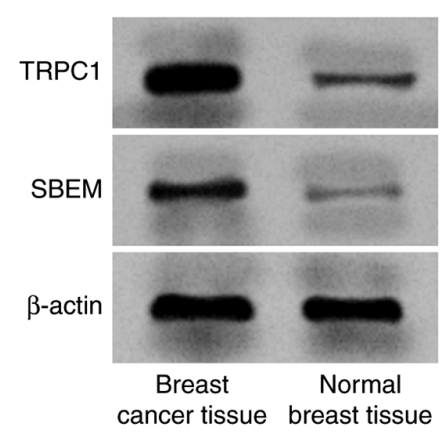

Figure 1. Comparison of relative expression results of TRPC1 and SBEM between breast cancer tissue and normal breast tissue. (A) Expression of TRPC1 in breast cancer tissues was significantly lower than that in normal breast tissues $(\mathrm{P}<0.001)$. (B) Expression of SBEM in breast cancer tissue was significantly higher than that in normal breast tissue $(\mathrm{P}<0.001)$. (C) Expression of TRPC1 related protein in breast cancer was significantly lower than that in normal breast tissue $(\mathrm{P}<0.001)$. (D) Expression of SBEM related protein in breast cancer was significantly lower than that of normal breast tissue $(\mathrm{P}<0.001)$. (E) Western blot. ${ }^{* * *} \mathrm{P}<0.001$.

tissues $(\mathrm{P}<0.001)$. However, the expression of SBEM protein and mRNA in breast cancer tissues was significantly higher than that in normal breast tissues $(\mathrm{P}<0.001$; Fig. 1).

Relationship between TRPC1 expression level and clinicopathological features of breast cancer. The expression of TRPC1 mRNA was not related to the age, tumor size or histological grade of breast cancer patients, but was related to TNM stage, clinical stage and lymph node metastasis (Table III).

The expression of TRPC1 protein was not related to the age, tumor size or histological grade of breast cancer patients, but was related to TNM stage, clinical stage and lymph node metastasis (Table IV).

Relationship between expression level of SBEM and clinicopathological characteristics of breast cancer. Expression of SBEM mRNA was not related to age, tumor size or histological grade of breast cancer patients, but was related to TNM staging and metastasis (Table V).

Expression of SBEM protein was not related to age, tumor size or histological grade of breast cancer patients, but was related to TNM staging and metastasis (Table VI).

Correlation between TRPCI and SBEM proteins in breast cancer of different clinical stages. The expression of TRPC1 in the tissues of patients at T1, T2, T3, and T4 of breast cancer were $(1.20 \pm 0.02),(1.50 \pm 0.02),(1.69 \pm 0.03)$, and $(2.02 \pm 0.03)$ respectively. Expression levels of SBEM were $(0.30 \pm 0.01),(0.35 \pm 0.01)$, $(0.50 \pm 0.01)$, and $(1.25 \pm 0.01)$. Compared with patients at $\mathrm{T} 1$, the relative expression of TRPC1 and SBEM in tissues of patients at $\mathrm{T} 2$ and $\mathrm{T} 3$ decreased significantly $(\mathrm{P}<0.05)$. With the increase of clinical stage, the relative expression of TRPC1 and SBEM in tissues increased continuously. The expression levels of TRPC1 in tissues at $\mathrm{T} 1, \mathrm{~T} 2, \mathrm{~T} 3$ and $\mathrm{T} 4$ were $(0.27 \pm 0.01),(0.35 \pm 0.02)$, $(0.43 \pm 0.02)$, and $(0.95 \pm 0.02)$. Expression levels of SBEM in different TNM stages of breast cancer were $(0.29 \pm 0.01)$, $(0.33 \pm 0.01),(0.55 \pm 0.01)$, and $(1.20 \pm 0.01)$. Compared with $\mathrm{T} 1$ patients, the relative expression of TRPC1 and SBEM in tissues at the other three stages decreased significantly $(\mathrm{P}<0.05)$. With the increase of clinical stage, the relative expression of TRPC1 and SBEM in tissues increased continuously. Stage I, II, III and IV of the TNM stage of the patient were set as 1,2, 3 and 4 respectively. Spearman correlation analysis of tissue TRPC1 and SBEM relative expression with different clinical stages of breast cancer showed that TRPC1 relative expression was positively correlated with clinical stages of breast cancer $(\mathrm{r}=0.992$, $\mathrm{P}<0.001)$. The relative expression of tissue SBEM was positively correlated with the clinical stage of breast cancer $(\mathrm{r}=0.853$, $\mathrm{P}<0.001)$. The relative expression of tissue TRPC1 was positively correlated with TNM staging of breast cancer $(\mathrm{r}=0.860$, $\mathrm{P}<0.001)$. The relative expression of SBEM was positively correlated with TNM staging of breast cancer $(r=0.880, P<0.001)$. That is, with the worsening of breast cancer, the expression of TRPC1 and SBEM increased (Figs. 2 and 3).

\section{Predictive value of TRPCI and SBEM protein in breast cancer} metastasis

Single factor analysis of breast cancer metastasis and related factors. Logistic single factor analysis of risk factors related to breast cancer metastasis in breast cancer patients showed that there were significant differences in age, clinical stage, TNM stage, TRPC1, and SBEM between breast cancer metastasis and breast cancer non-metastasis $(\mathrm{P}<0.05)$. The patient's age, 
Table IV. Relationship between TRPC1 protein expression and clinicopathological features of breast cancer.

\begin{tabular}{|c|c|c|c|c|}
\hline Group & $\mathrm{n}$ & TRPC1 & $\mathrm{t} / \mathrm{F}$ & P-value \\
\hline Age, years & & & 1.387 & 0.172 \\
\hline$\leq 50$ & 25 & $1.60 \pm 0.03$ & & \\
\hline$>50$ & 25 & $1.61 \pm 0.02$ & & \\
\hline Histological classification & & & 1.178 & 0.245 \\
\hline Level 1+level 2 & 26 & $1.60 \pm 0.03$ & & \\
\hline Level 3 & 24 & $1.61 \pm 0.03$ & & \\
\hline Tumor size, $\mathrm{cm}$ & & & 1.762 & 0.084 \\
\hline$\leq 2$ & 23 & $1.58 \pm 0.02$ & & \\
\hline$>2$ & 27 & $1.59 \pm 0.02$ & & \\
\hline Clinical staging & & & $1,837.000$ & $<0.001$ \\
\hline Phase I & 10 & $1.20 \pm 0.02$ & & \\
\hline Phase II & 17 & $1.50 \pm 0.02$ & & \\
\hline Phase III & 14 & $1.69 \pm 0.03$ & & \\
\hline Phase IV & 9 & $2.02 \pm 0.03$ & & \\
\hline TNM staging & & & $1,909.000$ & $<0.001$ \\
\hline $\mathrm{T} 1$ & 10 & $1.18 \pm 0.02$ & & \\
\hline $\mathrm{T} 2$ & 18 & $1.52 \pm 0.02$ & & \\
\hline $\mathrm{T} 3$ & 13 & $1.68 \pm 0.03$ & & \\
\hline $\mathrm{T} 4$ & 9 & $2.03 \pm 0.03$ & & \\
\hline Lymph node metastasis & & & 75.420 & $<0.001$ \\
\hline No & 40 & $1.20 \pm 0.03$ & & \\
\hline Yes & 10 & $2.00 \pm 0.03$ & & \\
\hline
\end{tabular}

TRPC1 expression level and age, histological grade, tumor size, clinical stage, TNM stage, lymph node metastasis.

A
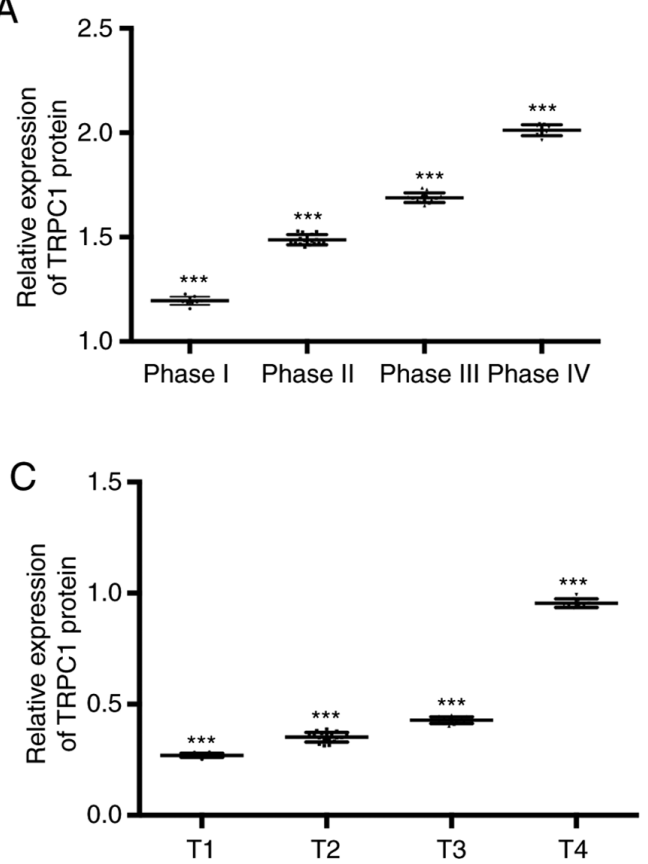

B

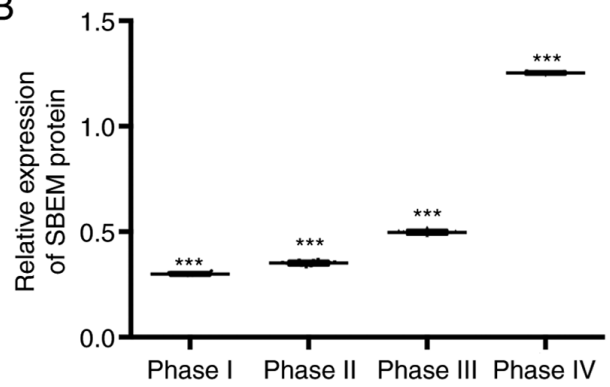

D

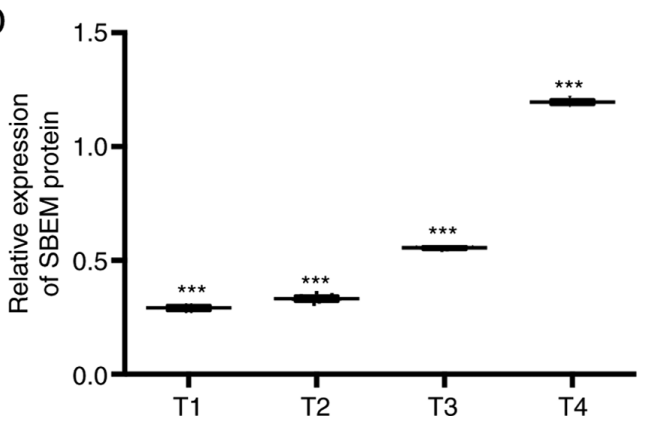

Figure 2. Relative expression of TRPC1 and SBEM in breast cancer tissues. (A) As the clinical stage of breast cancer increases, the relative expression of TRPC1 in tissues increases $(\mathrm{P}<0.05)$. ${ }^{* * *} \mathrm{P}<0.001$ indicates phases I and IV compared with phases II and III. (B) As the clinical stage of breast cancer increases, the relative expression of SBEM in tissues increases $(\mathrm{P}<0.05)$. ${ }^{* * *} \mathrm{P}<0.001$ indicates phases I and IV compared with phases II and III. (C) As the clinical stage of breast cancer increases, the relative expression of TRPC1 in tissues increases $(\mathrm{P}<0.05)$. ${ }^{* * *} \mathrm{P}<0.001$ indicates that phases I and IV compared with phases II and III. (D) As the clinical stage of breast cancer increases, the relative expression of $\mathrm{SBEM}$ in tissues increases $(\mathrm{P}<0.05)$. ${ }^{* * *} \mathrm{P}<0.001$ indicates phases I and IV compared with phases II and III. 
Table V. Relationship between mRNA expression of SBEM and clinicopathological characteristics of breast cancer.

\begin{tabular}{|c|c|c|c|c|}
\hline Group & $\mathrm{n}$ & SBEM & $\mathrm{t} / \mathrm{F}$ & P-value \\
\hline Age, years & & & 1.768 & 0.0834 \\
\hline$\leq 50$ & 25 & $0.50 \pm 0.02$ & & \\
\hline$>50$ & 25 & $0.51 \pm 0.02$ & & \\
\hline Histological classification & & & 1.767 & 0.837 \\
\hline Level 1+level 2 & 26 & $0.49 \pm 0.03$ & & \\
\hline Level 3 & 24 & $0.50 \pm 0.02$ & & \\
\hline Tumor size, $\mathrm{cm}$ & & & 1.631 & 0.109 \\
\hline$\leq 2$ & 23 & $0.50 \pm 0.03$ & & \\
\hline$>2$ & 27 & $0.51 \pm 0.01$ & & \\
\hline Clinical staging & & & $2,871.000$ & $<0.001$ \\
\hline Phase I & 10 & $0.25 \pm 0.01$ & & \\
\hline Phase II & 17 & $0.38 \pm 0.02$ & & \\
\hline Phase III & 14 & $0.40 \pm 0.02$ & & \\
\hline Phase IV & 9 & $0.97 \pm 0.02$ & & \\
\hline TNM staging & & & 2,687 & $<0.001$ \\
\hline $\mathrm{T} 1$ & 10 & $0.27 \pm 0.01$ & & \\
\hline $\mathrm{T} 2$ & 18 & $0.35 \pm 0.02$ & & \\
\hline $\mathrm{T} 3$ & 13 & $0.43 \pm 0.02$ & & \\
\hline $\mathrm{T} 4$ & 9 & $0.95 \pm 0.02$ & & \\
\hline Lymph node metastasis & & & 135.800 & $<0.001$ \\
\hline No & 40 & $0.30 \pm 0.01$ & & \\
\hline Yes & 10 & $0.90 \pm 0.02$ & & \\
\hline
\end{tabular}

SBEM mRNA expression level and age, histological grade, tumor size, clinical stage, TNM stage, lymph node metastasis.
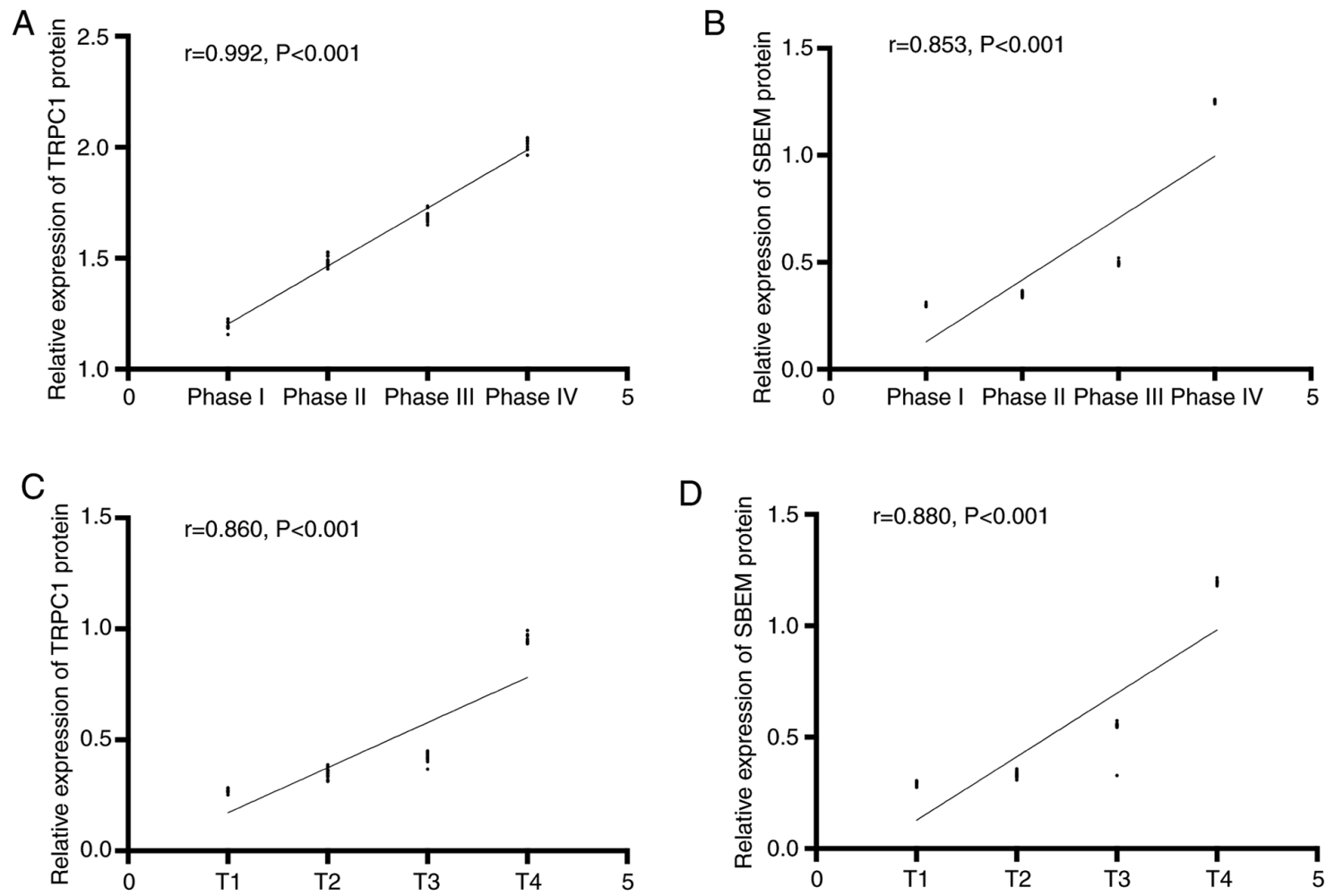

Figure 3. Correlation between relative expression of TRPC1, and SBEM in breast cancer tissues and clinical stages of breast cancer. (A) The relative expression of TRPC1 in tissues is positively correlated with the clinical stage of breast cancer $(\mathrm{r}=0.992, \mathrm{P}<0.001)$. (B) The relative expression of tissue SBEM is positively correlated with the clinical stage of breast cancer $(\mathrm{r}=0.853, \mathrm{P}<0.001)$. (C) The relative expression of tissue TRPC1 is positively correlated with TNM staging of breast cancer $(\mathrm{r}=0.860, \mathrm{P}<0.001)$. (D) The relative expression of tissue SBEM is positively correlated with TNM staging of breast cancer $(\mathrm{r}=0.880, \mathrm{P}<0.001)$. 
Table VI. Relationship between expression of SBEM protein and clinicopathological characteristics of breast cancer.

\begin{tabular}{|c|c|c|c|c|}
\hline Group & $\mathrm{n}$ & SBEM & $\mathrm{t} / \mathrm{F}$ & P-value \\
\hline Age, years & & & 0.000 & 0.999 \\
\hline$\leq 50$ & 25 & $0.59 \pm 0.02$ & & \\
\hline$>50$ & 25 & $0.59 \pm 0.01$ & & \\
\hline \multicolumn{5}{|l|}{ Histological classification } \\
\hline Level $1+$ level 2 & 26 & $0.59 \pm 0.02$ & 1.767 & 0.084 \\
\hline Level 3 & 24 & $0.60 \pm 0.02$ & & \\
\hline Tumor size, $\mathrm{cm}$ & & & 1.631 & 0.109 \\
\hline$\leq 2$ & 23 & $0.59 \pm 0.03$ & & \\
\hline$>2$ & 27 & $0.60 \pm 0.01$ & & \\
\hline Clinical staging & & & $1,916.000$ & $<0.001$ \\
\hline Phase I & 10 & $0.30 \pm 0.01$ & & \\
\hline Phase II & 17 & $0.35 \pm 0.01$ & & \\
\hline Phase III & 14 & $0.50 \pm 0.01$ & & \\
\hline Phase IV & 9 & $1.25 \pm 0.01$ & & \\
\hline TNM staging & & & $1,779.000$ & $<0.001$ \\
\hline $\mathrm{T} 1$ & 10 & $0.29 \pm 0.01$ & & \\
\hline $\mathrm{T} 2$ & 18 & $0.33 \pm 0.01$ & & \\
\hline $\mathrm{T} 3$ & 13 & $0.55 \pm 0.01$ & & \\
\hline $\mathrm{T} 4$ & 9 & $1.20 \pm 0.01$ & & \\
\hline Lymph node metastasis & & & 169.700 & $<0.001$ \\
\hline No & 40 & $0.30 \pm 0.01$ & & \\
\hline Yes & 10 & $0.90 \pm 0.01$ & & \\
\hline
\end{tabular}

SBEM expression level and age, histological grade, tumor size, clinical stage, TNM stage, lymph node metastasis.

Table VII. Assignments of factors related to breast cancer metastasis.

\begin{tabular}{lc}
\hline Correlative factor & Assignment description \\
\hline Age (years) & $<50=0 ; \geq 50=1$ \\
Histological classification & Level $1+$ Level $2=0 ;$ Level $3=1$ \\
Tumor size $(\mathrm{cm})$ & $\leq 2=0 ;>2=1$ \\
Clinical staging & Phase I-II $=0 ;$ Phase III-IV=1 \\
TNM staging & T0-T1 $=0 ;$ T2-T3 $=1$ \\
TRPC1 & $<0.90=0 ;>0.90=1$ \\
SBEM & $<0.90=0 ;>0.90=1$ \\
\hline
\end{tabular}

Assignments of the factors related to breast cancer metastasis.

clinical stage, TNM stage, TRPC1, SBEM were related to breast cancer metastasis and were risk factors for breast cancer metastasis, indicating that the risk of breast cancer increased with advanced age, worsening condition and high expression of TRPC1 and SBEM, as shown in Tables VII and VIII.

Multivariate analysis of breast cancer metastasis and related factors. Risk factors related to malignant breast cancer metastasis were analyzed by multivariate conditional Logistic regression. The results showed that TNM staging, TRPC1 and SBEM were independent risk factors for malignant breast cancer metastasis. Breast cancer is more prone to metastasis with increasing TNM stage, and breast cancer metastasis is closely related to TRPC1 and SBEM levels (Table IX).

\section{Discussion}

At present, the overall treatment effect for breast cancer patients is not ideal. In addition to the untimely diagnosis and treatment of early breast cancer patients, surgical resection at this stage has poor treatment effect for breast cancer patients with lymph node metastasis, and the recurrence rate of patients is extremely high (14). Traditional pathological section examination and imaging examination can accurately diagnose the condition of breast cancer patients, but it is difficult to monitor the development and changes of specific conditions of breast cancer. In particular, it is not sensitive to whether cancer is transferred from breast tissue to outside the breast in the early stage (15). The key to reduce the recurrence rate and the mortality rate of breast cancer is to accurately diagnose the condition of the breast cancer and to establish the corresponding treatment plan (16). With the deepening research on oncogenes, tumor suppressor genes and related regulatory proteins, it is of great significance to analyze the development mechanism of breast cancer based on the molecular biology of tumors to explore new therapeutic methods (17). 
Table VIII. Single factor analysis of breast cancer metastasis and related factors.

\begin{tabular}{|c|c|c|c|c|}
\hline Factor & $\begin{array}{l}\text { Metastasis of breast } \\
\text { cancer }(n=10)\end{array}$ & $\begin{array}{c}\text { Non-metastatic } \\
\text { breast cancer }(n=40)\end{array}$ & $\mathrm{t} / \chi^{2}$ & P-value \\
\hline Age, years & & & 2.000 & 0.157 \\
\hline$\leq 50$ & $3(30.00)$ & $22(55.00)$ & & \\
\hline$>50$ & $7(70.00)$ & $18(45.00)$ & & \\
\hline Histological classification & & & 0.017 & 0.897 \\
\hline Level 1+level 2 & $5(50.00)$ & $21(52.50)$ & & \\
\hline Level 3 & $5(50.00)$ & $19(47.50)$ & & \\
\hline Tumor size, $\mathrm{cm}$ & & & 0.181 & 0.670 \\
\hline$\leq 2$ & $4(40.00)$ & $19(47.50)$ & & \\
\hline$>2$ & $6(60.00)$ & $21(52.50)$ & & \\
\hline TNM staging & & & 25.850 & $<0.001$ \\
\hline $\mathrm{T} 1$ & $0(0.00)$ & $10(25.00)$ & & \\
\hline $\mathrm{T} 2$ & $0(0.00)$ & $18(45.00)$ & & \\
\hline $\mathrm{T} 3$ & $3(30.00)$ & $10(25.00)$ & & \\
\hline $\mathrm{T} 4$ & $7(70.00)$ & $2(5.00)$ & & \\
\hline Clinical staging & & & 16.020 & 0.001 \\
\hline Phase I & $0(0.00)$ & $10(25.00)$ & & \\
\hline Phase II & $0(0.00)$ & $17(42.50)$ & & \\
\hline Phase III & $5(50.00)$ & $9(22.50)$ & & \\
\hline Phase IV & $5(50.00)$ & $4(10.00)$ & & \\
\hline TRPC1 & $0.90 \pm 0.02$ & $0.30 \pm 0.01$ & 135.800 & $<0.001$ \\
\hline SBEM & $0.90 \pm 0.01$ & $0.30 \pm 0.01$ & 169.700 & $<0.001$ \\
\hline
\end{tabular}

Single factor analysis of metastasis and non-metastasis of breast cancer and related factors.

Table IX. Multivariate analysis of breast cancer metastasis and related factors.

\begin{tabular}{lcccccl}
\hline Factor & $\beta$ & SE & Wald & P-value & Exp $(\beta)$ & $95 \%$ CI \\
\hline TNM staging & 1.133 & 1.667 & 0.492 & 0.041 & 1.568 & $1.244-22.018$ \\
Clinical staging & 0.974 & 1.802 & 1.028 & 0.009 & 1.209 & $0.081-4.680$ \\
TRPC1 & 1.362 & 1.714 & 0.515 & 0.015 & 2.493 & $0.154-19.200$ \\
SBEM & 1.025 & 1.519 & 0.438 & 0.027 & 0.520 & $0.012-4.205$ \\
\hline
\end{tabular}

Multivariate conditional logistic regression analysis show that TNM stage, TRPC1 and SBEM are independent risk factors for breast cancer metastasis.

In this study, the mRNA and protein differences in TRPC1 and SBEM of breast cancer patients and normal breast cancer tissues were detected by qRT-PCR and Western blot techniques. The results showed that the expression of TRPC1 and SBEM in breast cancer tissues was significantly higher than that in normal breast tissues, and the difference was statistically significant. TRPC1 can affect the biological function of tumor cells by regulating gene expression and relevant tumor signal pathways, thus affecting the development of tumors (18). As a tumor-related antigen, SBEM is usually highly expressed in tumor cells. At present, SBEM has been confirmed to be up-regulated in normal breast tumor cells and can be used as a new marker for detecting micrometastasis and early diagnosis of breast cancer $(19,20)$. TRPC1, as a potential target molecule for diagnosis and treatment of early breast cancer, is abnormally elevated in a variety of tumor tissues including breast cancer. Some research indicates that it can play a role in inducing apoptosis of breast cancer cells by inhibiting expression of apoptosis protein-related proteins $(21,22)$. By constructing specific TRPC1 siRNA expression vector and lentivirus vector mediated TRPC1 siRNA interference system, transfecting cells and establishing stable passage cell lines, it was found that after down-regulation of TRPC1 gene, breast cancer cell proliferation, invasion and migration ability were down-regulated, and apoptosis rate of cancer cells increased $(23,24)$. Therefore, we consider that both TRPC1 
and SBEM are up-regulated in breast cancer tissues. Then the clinical data of breast cancer patients was explored and it was found that the expression of TRPC1 and SBEM was related to TNM stage, clinical stage and lymph node metastasis of breast cancer. At present, although there is no specific study on TNM staging, metastasis, TRPC1 and SBEM of breast cancer, there are reports on the relationship between target protein regulation and breast cancer. It was suggested that the expression of TRPC1 detected by qRT-PCR technology showed a decreasing trend in breast cancer tissues, and miRNA expression in patients with different TNM staging, lymph node metastasis and non-metastasis was further detected by experiments. It was found that the high TNM stage was closely related to the high expression of TRPC1 in lymph node metastasis cancer tissue, indicating that the expression change of TRPC1 was related to the breast cancer metastasis and clinical pathological stage, which is similar to the results of this study and is an excellent auxiliary evidence for the results of this study (25). Then, we analyzed the correlation between TRPC1 and SBEM in breast cancer of different clinical stages and TNM stages, and found that the relative expression of TRPC1 and SBEM in tissues increased with the increase of clinical and TNM stages, and the relative expression of TRPC1 and SBEM were positively correlated with clinical stage and TNM stage of breast cancer. miRNAs and related proteins have been proved to be closely related to tumor staging. The expression level of miRNAs increased or decreased significantly with tumor staging by inhibiting or promoting tumor in different tumors (26). Finally, we analyzed the risk factors related to breast cancer metastasis in breast cancer patients by Logistic single factor analysis, and found that clinical stage, TNM stage and lymph node metastasis were important prognostic factors of patients (27). However, there has been no previous study on the diagnostic efficacy and predictive value of TRPC1 and SBEM expression changes in breast cancer metastatic tissues. In this study, TRPC1 and SBEM showed certain predictive value for the diagnosis and prognosis of breast cancer metastasis.

This study confirmed the expression of TRPC1 and SBEM in breast cancer patients and their predictive value, but there are still some deficiencies in the study. There is no specific analysis of the regulatory effects of TRPC1 and SBEM expression changes on breast cancer cells, or further explanation of their biological functions. TRPC1 and SBEM, as clinical routine tumor markers, were analyzed, which have certain influence on the accuracy of research results. Therefore, further study is still necessary.

Collectively, the expression of TRPC1 and SBEM in breast cancer tissues is up-regulated. TRPC1 and SBEM may be involved in the process of breast cancer occurrence, development and metastasis, and can be used as potential tissue biomarkers for diagnosis of breast cancer metastasis and for disease assessment.

\section{Acknowledgements}

Not applicable.

\section{Funding}

No funding was received.

\section{Availability of data and materials}

The datasets used and/or analyzed during the present study are available from the corresponding author on reasonable request.

\section{Authors' contributions}

YZ wrote the manuscript, analyzed and interpreted the patient data. XL performed the PCR and the western blot analysis. WG assisted $f$ with statistical analysis. All authors read and approved the final manuscript.

\section{Ethics approval and consent to participate}

The study was approved by the Ethics Committee of Weifang People's Hospital (Weifang, China). Patients who participated in this research had complete clinical data and signed informed consents were obtained from the patients and/or guardians.

\section{Patient consent for publication}

Not applicable.

\section{Competing interests}

The authors declare that they have no competing interests.

\section{References}

1. Arun G and Spector DL: MALAT1 long non-coding RNA and breast cancer. RNA Biol 16: 860-863, 2019.

2. Kennedy SP, Han JZR, Portman N, Nobis M, Hastings JF, Murphy KJ, Latham SL, Cadell AL, Miladinovic D, Marriott GR, et al: Targeting promiscuous heterodimerization overcomes innate resistance to ERBB2 dimerization inhibitors in breast cancer. Breast Cancer Res 21: 43, 2019.

3. Ishay-Ronen D, Diepenbruck M, Kalathur RKR, Sugiyama N, Tiede S, Ivanek R, Bantug G, Morini MF, Wang J, Hess C and Christofori G: Gain fat-lose metastasis: Converting invasive breast cancer cells into adipocytes inhibits cancer metastasis. Cancer Cell 35: 17-32. e6, 2019.

4. Benjamin MA, Sinnott C, Bawa S, Kaufman DI, Guarino K and Addona T: Re-excision rate after partial mastectomy in oncoplastic breast-conserving surgery: A single-institutional experience and review of the literature. Ann Plast Surg 82 (4S Suppl 3): S170-S172, 2019.

5. Kaczmarski K, Wang P, Gilmore R, Overton HN, Euhus DM, Jacobs LK, Habibi M, Camp M, Weiss MJ and Makary MA: Surgeon re-excision rates after breast-conserving surgery: A measure of low-value care. J Am Coll Surg 228: 504-512.e2, 2019.

6. Chen IX, Chauhan VP, Posada J, Ng MR, Wu MW, Adstamongkonkul P, Huang P, Lindeman N, Langer R and Jain RK: Blocking CXCR4 alleviates desmoplasia, increases T-lymphocyte infiltration, and improves immunotherapy in metastatic breast cancer. Proc Natl Acad Sci USA 116: 4558-4566, 2019.

7. Baker E, Whiteoak N, Hall L, France J, Wilson D and Bhaskar P: Mammaglobin-A, VEGFR3, and Ki67 in human breast cancer pathology and five year survival. Breast Cancer (Auckl) 13: $1178223419858957,2019$.

8. Malmgren J, Hurlbert M, Atwood M and Kaplan HG: Examination of a paradox: Recurrent metastatic breast cancer incidence decline without improved distant disease survival: 1990-2011. Breast Cancer Res Treat 174: 505-514, 2019.

9. Esteva FJ, Hubbard-Lucey VM, Tang J and Pusztai L: Immunotherapy and targeted therapy combinations in metastatic breast cancer. Lancet Oncol 20: e175-e186, 2019. 
10. Maeda SS, Borba VZ, Camargo MB, Silva DM, Borges JL, Bandeira F and Lazaretti-Castro M; Brazilian Society of Endocrinology and Metabology (SBEM): Recommendations of the Brazilian society of endocrinology and metabology (SBEM) for the diagnosis and treatment of hypovitaminosis D. Arq Bras Endocrinol Metabol 58: 411-433, 2014 (In Portuguese).

11. Sambale M, Intemann J, Pap T and Sherwood J: A homeostatic role for transient receptor potential cation channel (TRPC1) in articular cartilage. Osteoarthriti Cartilage 27: S175, 2019.

12. Selli C, Pearce DA, Sims AH and Tosun M: Differential expression of store-operated calcium- and proliferation-related genes in hepatocellular carcinoma cells following TRPC1 ion channel silencing. Mol Cell Biochem 420: 129-140, 2016.

13. Finn RS, Martin M, Rugo HS, Jones S, Im SA, Gelmon K, Harbeck N, Lipatov ON, Walshe JM, Moulder S, et al: Palbociclib and letrozole in advanced breast cancer. N Engl J Med 375: 1925-1936, 2016.

14. Swain SM, Baselga J, Kim SB, Ro J, Semiglazov V, Campone M, Ciruelos E, Ferrero JM, Schneeweiss A, Heeson S, et al: Pertuzumab, trastuzumab, and docetaxel in HER2-positive metastatic breast cancer. N Engl J Med 372: 724-734, 2015.

15. Wang D, Khosla A, Gargeya R, Irshad H and Beck A: Deep learning for identifying metastatic breast cancer. arXiv preprint arXiv: 1606.05718, 2016.

16. Murtaza M,Dawson SJ, Pogrebniak K, Rueda OM, Provenzano E, Grant J, Chin SF, Tsui DWY, Marass F, Gale D, et al: Multifocal clonal evolution characterized using circulating tumour DNA in a case of metastatic breast cancer. Nat Commun 6: 8760, 2015.

17. Pavan S, Meyer-Schaller N, Diepenbruck M, Kalathur RKR, Saxena M and Christofori G: A kinome-wide high-content siRNA screen identifies MEK5-ERK5 signaling as critical for breast cancer cell EMT and metastasis. Oncogene 37: 4197-4213, 2018.

18. Grant CV, Carver CM, Hastings SD, Ramachandran K, Muniswamy M, Risinger AL, Beutler JA and Mooberry SL: Triple-negative breast cancer cell line sensitivity to englerin A identifies a new, targetable subtype. Breast Cancer Res Treat 177: 345-355, 2019.

19. Xue D, Xia T, Wang J, Chong M, Wang S and Zhang C: Role of regulatory $\mathrm{T}$ cells and $\mathrm{CD}^{+} \mathrm{T}$ lymphocytes in the dissemination of circulating tumor cells in primary invasive breast cancer. Oncol Lett 16: 3045-3053, 2018.
20. Johnston APR, Rae J, Ariotti N, Bailey B, Lilja A, Webb R, Ferguson C, Maher S, Davis TP, Webb RI, et al: Journey to the centre of the cell: Virtual reality immersion into scientific data. Traffic 19: 105-110, 2018.

21. O'Grady S and Morgan MP: Microcalcifications in breast cancer: From pathophysiology to diagnosis and prognosis. Biochim Biophys Acta Rev Cancer 1869: 310-320, 2018.

22. Kaemmerer E, Turner D, Peters AA, Roberts-Thomson SJ and Monteith GR: An automated epifluorescence microscopy imaging assay for the identification of phospho-AKT level modulators in breast cancer cells. J Pharmacol Toxicol Methods 92: 13-19, 2018

23. Abdoul-Azize S, Buquet C, Li H, Picquenot JM and Vannier JP: Integration of $\mathrm{Ca}^{2+}$ signaling regulates the breast tumor cell response to simvastatin and doxorubicin. Oncogene 37: 4979-4993, 2018.

24. Pu Q, Zhao Y, Sun Y, Huang T, Lin P, Zhou C, Qin S, Singh BB and Wu M: TRPC1 intensifies house dust mite-induced airway remodeling by facilitating epithelial-to-mesenchymal transition and STAT3/NF- $\kappa$ B signaling. FASEB J 33: 1074-1085, 2018.

25. Xu Z, Shao Z, Wang M, Thorndike EH, Song Y and Shang ZJ: Expression of transient receptor potential canonical 1 (TRPC1) in tongue squamous cell carcinoma and correlations with clinicopathological features and outcomes. Int J Clin Exp Pathol 10: 1477-1487, 2017.

26. Pu Q, Huang Y, Lu Y, Peng Y, Zhang J, Feng G, Wang C, Liu L and Dai Y: Tissue-specific and plasma microRNA profiles could be promising biomarkers of histological classification and TNM stage in non-small cell lung cancer. Thorac Cancer 7: 348-354, 2016.

27. Goldstraw P, Chansky K, Crowley J, Rami-Porta R, Asamura H, Eberhardt WE, Nicholson AG, Groome P, Mitchell A, Bolejack $\mathrm{V}$, et al: The IASLC lung cancer staging project: Proposals for revision of the TNM stage groupings in the forthcoming (Eighth) edition of the TNM classification for lung cancer. J Thorac Oncol 11: 39-51, 2016. 